\title{
The Role of Netiquettes in Establishing Relationships in Virtual Learning Communities
}

\author{
Abdelmajid JAMIAI \\ Moulay Ismail University, Morocco \\ amjamiai@gmail.com
}

$\begin{array}{ll}\begin{array}{l}\text { Received: } \\ \text { 20/07/2019 }\end{array} & \text { Abstract } \\ \text { In the era of digital literacy, human relationships in virtual learning } \\ \text { Accepted: } \\ \text { communities are governed by much social behavior that many students in } \\ \text { higher education respect, in some cases, while others are rebellious } \\ \text { against them. The aim of this article is to investigate if there is a } \\ \text { correlation between 'netiquettes', which are the guidelines that should be } \\ \text { Keywords: } \\ \text { Netiquettes, } \\ \text { Face-to-Face, } \\ \text { Online } \\ \text { Communication, } \\ \text { Relationships, } \\ \text { Gender } & \text { the Faculty of Letters and Human Sciences in Moulay Ismail University in } \\ & \text { Meknes, Morocco. A questionnaire has been administered to measure the } \\ \text { predicted relationship between netiquettes and relationship building. The } \\ \text { sample includes fifty male and female respondents. The findings of the } \\ \text { study indicate that there is a significant relationship between respecting } \\ \text { netiquettes and building online relationships, set as a hypothesis for this } \\ \text { study. The significance of the study lies in raising the university students' } \\ \text { awareness of respecting the netiquettes in online learning groups, which } \\ \text { might contribute to academic research in the field of online communication } \\ \text { behavior. }\end{array}$

\section{INTRODUCTION}

Social behavior dates back to the naissance of humanity. Recently, much interest has been devoted to research in human relationships with their strengths and breakdowns. In the ongoing swift change from communicating in face-to-face to online communication, researchers embark on those hidden issues that may uncover both realities. In this respect, 'Netiquettes' or 'Network Etiquettes' is given a space, though insufficient in the literature in comparison to other online subjects, to be looked into. Netiquette is lexically the fusion of 'network' with 'etiquette' to refer to the social norms that should be adopted by online users while belonging to a virtual learning environment so as to interact. This interactivity, though free, is constrained by some limits that should not be surpassed. Thus, netiquettes are seen as a replica of social etiquettes.

The blending of the concept 'netiquette' conveys not only the morphological composition of the word but the fusion of adapting two worlds: the real and the virtual. As an Internet user, the degree of responsibility varies among users with regard to the rules and conventions that dictate the restrictions to be respected like the case of face-to-face communication. Interacting in the real world bans any violation of the transmission principles. However, when online, some 
users deny the already established rules in a learning virtual group by being rebellious against the netiquettes that promote solid grounds in the erection of social online connection.

To delve into the matter, it is deemed necessary to refer to Post (1955: 46) who defines etiquettes as "those with vivid imaginations are often unreliable in their statements" (cited in Wood and Smith, 2004: 134). This means that the speaker does not need to be as brilliant as society dictates but to be trustworthy in the process of communication within the social norms. Moreover, the participant is seized as real in the contact of others. On the other side of the coin, Shea (1994: 33) introduced 'netiquette' as to "Make yourself look good online: know what you're talking about and make sense" (Shea, 1994: 33 cited in Wood and Smith, 2004: 134). According to Shea, the netiquette has to do with the user's reputation online. In other words, having a superb image is basically dependent on the meaning of what you discuss. This makes the netiquette as a boycott with misbehaving in a virtual community as if reality with its social backgrounds would be reflected on the web.

Since acting on the web is confined to online communities, Wood and Smith (2004) state that "virtual communities establish rules that they expect their members to observe. Any number of the rules governing accepted behavior has been codified as Internet etiquette, or netiquette" (p. 134). Wood and Smith back up the idea that a newbie who would like to join the online group is expected to be obedient to the regulations set by the members of the community. So, etiquettes provide netizens with guidelines to pursue. Thus, the purpose of netiquette is not only for adding a human element to the group but also to make communication more effective.

Irina (2016) declares that "Netiquette, or Network Etiquette, which stipulates rules for communication via the Internet, is more and more recognized by educators as an indispensable component of students` initiation into effective use of Computer-Mediated Communication" ( $p$. 29). For Irina, netiquettes in relation to education give the impression that CMC is in need of successful users to set and respect the normative skills of communication. Yet, "it is not surprising that non-native speakers often succumb to the seeming freedom and anarchy of electronic medium" (Ibid). Since the article is dealing with the Moroccan context where speakers of English are not native, the computer is wrongly used due to the free access of the machine.

Joseph Kayany (2004: 1) introduces the netiquette as "a blend of common sense, common courtesy, and dictates of the computer technology and culture established by Internet users" (Miller, 2001). In this realm, netiquette is the outcome of commonalities, fusing intellectualism and politeness in which online group members build their own cultural aspects in the course of technology. Therefore, Internet users' behaviors in the real world are replicated in the virtual community. Shea (1994) suggests that "compliance with socially defined behavioral norms is the ticket for entry to a network or society". The researcher's focus is on the fact that online users' manners should conform to the group as a prerequisite to have access to the networked society (Cited in Joseph Kayany, 2004: 1).

Joseph kayany (2004) continuously describes significant details about the netiquette space and the roles group members they play. Accordingly, the setting is referred to as "virtual communities' where the group users have the possibility to access virtual locations "where messages classified by topic were stored in a chronological order. Geographically dispersed 
users were drawn to these shared spaces because of shared interests. Their posts and responses were experienced as group communication activities that led to group bonding, affinity, and identity." Joseph (2004) depicts that group participants, though special distance, formulate a combination of time, distance, activity and identity characteristics. These traits distinguish online communication from the real one by means of having the capability of gathering the scattered population together in one site (p. 3). This makes Virginia Shea set ten rules of netiquettes.

To elaborate on Shea's rules of social online behavior, "remember the human" invokes the use of cognition and awareness. Differently put, the user is advised to keep in mind the most common feature that is portrayed in the human side. From the side of other participants, all human beings have basic needs among which care is considered. In the same context, the idea of human remembrance makes participants more empathetic by putting themselves in the shoes of other online friends. Thus, being careful and aware in online learning communities facilitates friendship construction and prepares grounds for a social environment badly needed in instilling reciprocal respect among online communities.

"To adhere to the same standards of behavior online that you follow in real life" is the second rule which appeals to the idea that every new joiner has to stick to the established values in the online learning environment which are common and deeply-rooted in the real world communication. Third, "Know where you are in cyberspace. "Lurk before you leap"." The third norm indicates that lurking should precede the full integration in the group. So, before any supposed activity within the group, the newbie is expected to cover the maximum of the shared and discussed issues so as to avoid being mistaken by breaking the rules of the bound participants. Thus, the knowledge principle in the online environment is a priori to get knowledgeable about the limits that should not be gone beyond. The fourth guideline is to "Respect other people's time and bandwidth." In other words, the notion of time is valued that's why every shared piece of information should be concise and precise. Moreover, establishing relationships needs care of the bandwidth because many people are subscribed for a purpose. The fifth tenet is to "Make yourself look good online." Every participant has to be positive while thinking of belonging to the bandwidth. Being good necessitates having positive qualities such as mutual respect and the use of politeness hints like salutations. Additionally, behaving in an intimate way can strengthen the acquaintance with the group.

The sixth decree is to "Share expert knowledge." The case is evidence for expertise in the online learning group. Members of the group should not behave in an ordinary manner but in a more professional way that suits the requirements of the group. The seventh declaration has to do with controlling causes of disruptions and conflicts. Thus, to "Help keep flame wars under control" is determined to create misunderstandings by sharing sensitive messages or comments that may result in negative emotional reactions within the group. The eighth statement asserts to "respect other's privacy". This means that every individual should not make other members' secrets public outside the group with the intention to abuse. Furthermore, private issues of others should not be shared within the group without the concerned person's consent. The ninth claim is to avoid abusing one's power. It is possible that one of the members of the online group is more experienced than other participants in the common field and he or she may misuse his/her knowledge to exercise his/her superiority over the whole group. However, participants should not underestimate other members and ought to believe in the online democracy for which 
technology has been created. The tenth and the last regulation for Shea is to "be forgiving of other people's mistakes." The idea of forgiveness is among the solid grounds upon which trust, respect and relationships are based. Consequently, by being peaceful and comprehensive, the online learning group can develop social behavior but not to revolt against the netiquette (Cited in Wood and Smith, 2004: 135).

\subsection{Research Gap}

Although researchers have dealt with "netiquettes" in the Western context, there is still a lack or absence of studies in Morocco. Therefore, the study will try to bridge the gap in the scientific area for Moroccan and international researchers who might have interest in netiquettes in virtual learning communities, embodied in the use of computer-mediated communication.

\subsection{Objectives of the Study}

Basing on the fact that human relationships have been constructed in face-to-face, and the role society has been playing to socialize new born people, behavior is so important to get to the point of effective styles of communication. Thus, one of the objectives of this study is to make online learners aware of transmitting good behaviors in real life to the virtual space since there is a growing subscription in online communities. Second, belonging to a certain group increases multiple qualities (trust, disclosure, help, sharing, learning, etc.), yet the academic side should be nurtured. The article aims to find out about the mechanisms and guidelines to develop students' professionalism in their online integration.

\subsection{Research Hypothesis}

The article tries to test one hypothesis: "When students in higher education respect netiquettes or network etiquettes, social relationships in learning are constructed". In the same scope, the study tries to confirm or disconfirm the hypothesis.

\subsection{Research Questions}

There are three research questions that this study tries to fulfill:

1- Is there any correlation between the age factor and respecting (n)etiquettes in face-to-face and online?

2- Do students in online learning communities practice netiquettes?

3- Does gender affect respecting netiquettes in online learning environments?

\section{METHODOLOGY}

The type of the study adopted in this article is the single instrumental case study. Stake (1995) states that the "researcher focuses on an issue or concern, and then selects one bounded case to illustrate this issue" (Stake, 1995 cited in Creswell, 2007: 74). In this article, the one selected group is that of the Facebook and the main issue of interest is netiquette.

\subsection{Sampling}

The convenient or non-probability sampling is followed to collect data using the questionnaire as an instrument, addressing one group of online learning group set by students of the Faculty of Letters and Human Sciences in Moulay Ismail University in Meknes. The members of the group join the page of Facebook for many purposes. Students can ask questions concerning courses, professors, schedules, and other personal inquiries such as information about 
administrative services. So, not all the students were given the questionnaire, but only those who belong to the Facebook community were allowed to fill it in.

\subsection{Data Collection and Analysis}

Fifty respondents participated in replying to the administered questionnaire. The collected data is to be measured statistically, using the SPSS (Statistical Package for Human Sciences). A very short description of the Facebook group, English department-Moulay Ismail-University, under study shows that it is a closed group, so a sending request is needed to join and any member of the group has the possibility to accept the request. However, any posting from an already-existing member of the group requires the administrator's (or Admin) approval. The most striking information in the first entry are the guidelines set by the Admin: "Here all your posts are accepted as long as they are related to English studies and information that concern a need of every student [who] belongs to this group, whether be a picture, video, status or file" (The Admin).

Depending on the Admin's guidelines, students should respect those words as a signed agreement before joining. Students are expected to respect those netiquettes related to the common field for which the group has been set. This clearly demonstrates that the Admin is already aware of the netiquettes but my study is to investigate the extent to which "newbies" (new comers from face-to-face) respect the norms of the online group in learning.

\section{RESULTS}

The pie-chart below shows the number of participants in the study from a gender perspective. Both males and females are equally selected; each gender represents $50 \%$ from the whole sample $(\mathrm{n}=50)$.

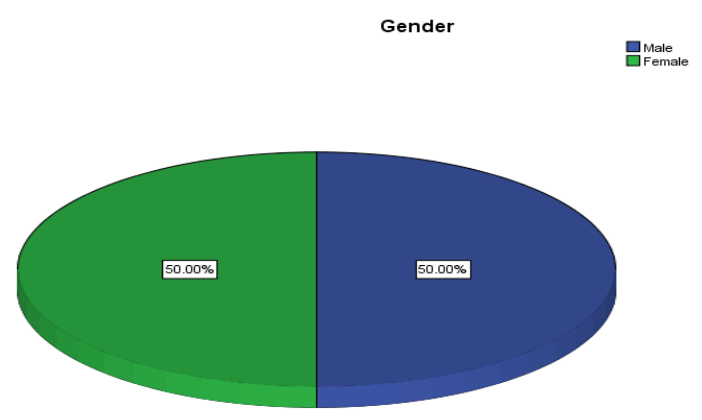

Figure 1. : Distribution of respondents by gender

Table 1. Reliability Statistics

\begin{tabular}{cc}
\hline Cronbach's Alpha & $\mathrm{N}$ of Items \\
\hline .946 & 24 \\
\hline
\end{tabular}

The internal reliability of the questionnaire items is tested by Cronbach's alpha coefficient test which is proven to be a good gauge that a researcher has to adopt before starting the distribution and the examination of any set of questions. Mallery (2003) provides the following rules of 
thumb: “_> $.9-$ Excellent, ${ }_{-}>.8-$ Good, ${ }_{-}>.7-$ Acceptable, ${ }_{-}>.6$ - Questionable, ${ }_{-}>.5-$ Poor and ${ }_{-}<.5$ - Unacceptable" (231). Table (1) above shows that the reliability of the 24 items in the questionnaire addressed to students is .94. This means that Cronbach's Alpha test indicates an excellent internal consistency among the 24 items. After collecting and measuring data, the results are described as follows.

Table 2. Age and respect of etiquettes in face-to-face communication

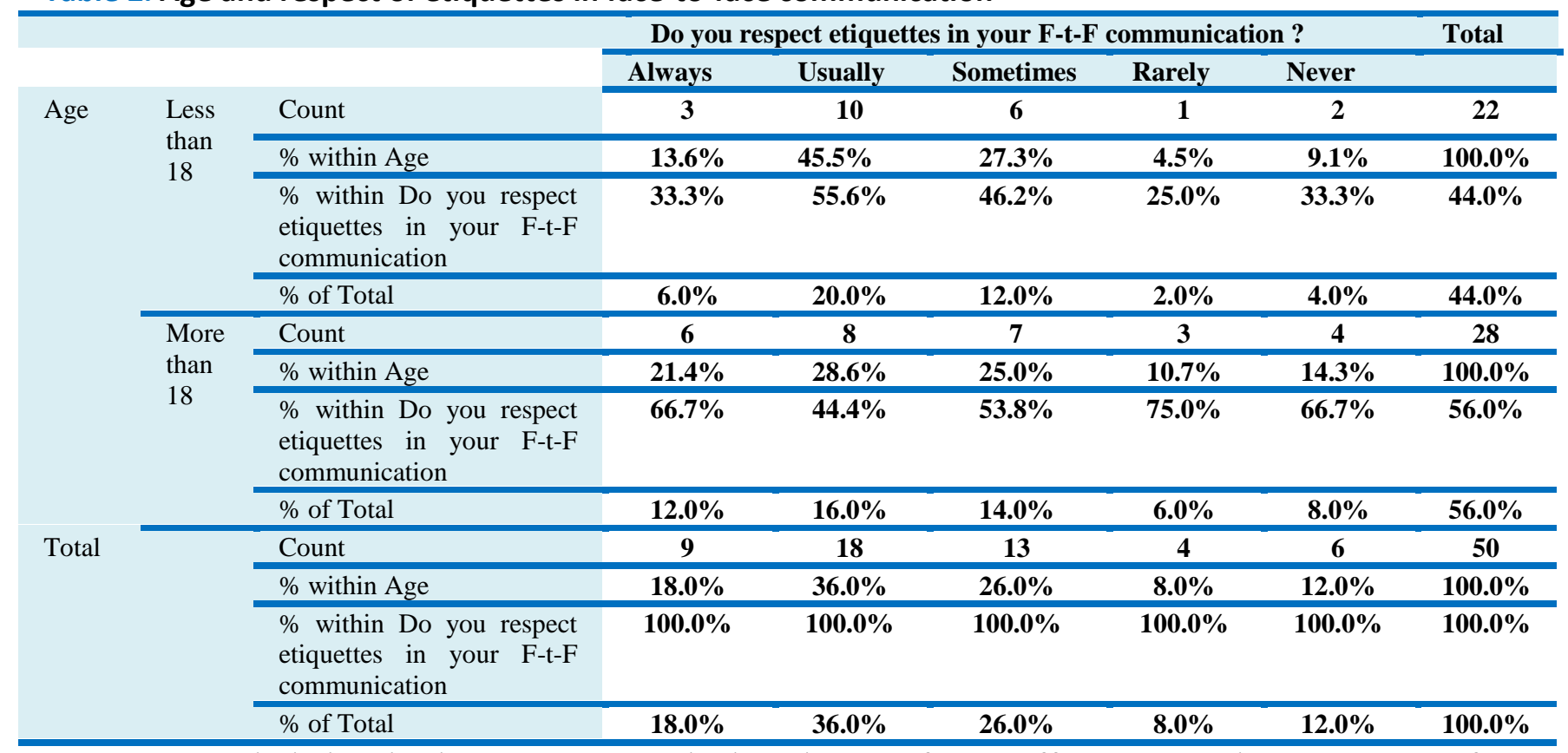

The cross-tabulation is done to assess whether the age factor affects respondents' respect of etiquettes in face-to-face communication. As it has been stated earlier, the age division is composed of "less than 18" and "more than 18". According to the table above, findings show that 3 respondents who represent $6 \%$ of the whole sample $(n=50)$ who "always" respect etiquettes in face-to-face communication who are 'less than 18 '. For the same age categorization, 10 respondents, representing $20 \%$, opt for "usually" option in the five scales, while "sometimes" is chosen by 6 respondents, rated as $12 \%$ from the whole sample. For "rarely", there is 1 respondent $(2 \%)$, and for those who "never" respect face-to-face etiquettes are confined to 2 respondents, referred to as $4 \%$. Respondents who are "more than 18 " are found to "always" respect face-to-face etiquettes and whose scores are represented in 9 elements with $18 \%$ from the whole sample $(n=50)$. "Usually" is the highest score by 18 respondents with $(36 \%)$, while "sometimes" is selected by 13 respondents with (26\%). 4 respondents from the whole sample $(n=50)$ who "rarely" respect the etiquettes, but for "never", 6 respondents with $(12 \%)$ are found to respect the etiquettes. Above all, the 28 students who are "more than 18 " with $(56 \%)$ are found to approximately respect etiquettes in face-to-face communication in comparison to the 22 "less than 18 " students with (22\%).

Table 3: Chi-Square Tests of the age factor and respecting etiquettes in face-to-face communication 
The Role of Netiquettes in Establishing Relationships in Virtual Learning Communities

\begin{tabular}{lccc}
\hline & Value & df & Asymp. Sig. (2-sided) \\
\hline Pearson Chi-Square & $2.279^{\mathrm{a}}$ & 4 & .685 \\
\hline Likelihood Ratio & 2.323 & 4 & .677 \\
\hline Linear-by-Linear Association & .260 & 1 & .610 \\
\hline N of Valid Cases & 50 & & \\
\hline
\end{tabular}

The above table about the Chi-square test shows that the $p$-value (.685) is not significant because the sig. value is higher than (.05) that is the average value to be significant. Thus, the null hypothesis is retained, meaning that there is no relationship between the age factor and respecting etiquettes in face-to-face communication.

\section{Table 4: Age and respect of netiquettes in online communication}

\begin{tabular}{|c|c|c|c|c|c|c|c|c|}
\hline \multirow{10}{*}{ Age } & \multirow{6}{*}{$\begin{array}{l}\text { Less } \\
\text { than } 18\end{array}$} & \multirow[b]{3}{*}{ Count } & \multicolumn{5}{|c|}{ Do you respect netiquettes in your online communication? } & \multirow[t]{2}{*}{ Total } \\
\hline & & & Always & Usually & Sometimes & Rarely & Never & \\
\hline & & & 5 & 9 & 3 & 2 & 3 & 22 \\
\hline & & $\%$ within Age & $22.7 \%$ & $40.9 \%$ & $13.6 \%$ & $9.1 \%$ & $13.6 \%$ & $100.0 \%$ \\
\hline & & $\begin{array}{l}\% \text { within Do you } \\
\text { respect netiquettes in } \\
\text { your online } \\
\text { communication }\end{array}$ & $45.5 \%$ & $\mathbf{5 0 . 0 \%}$ & $50.0 \%$ & $22.2 \%$ & $\mathbf{5 0 . 0 \%}$ & $44.0 \%$ \\
\hline & & $\%$ of Total & $10.0 \%$ & $18.0 \%$ & $6.0 \%$ & $4.0 \%$ & $6.0 \%$ & $44.0 \%$ \\
\hline & More & Count & 6 & 9 & 3 & 7 & 3 & 28 \\
\hline & than 18 & $\%$ within Age & $21.4 \%$ & $32.1 \%$ & $10.7 \%$ & $25.0 \%$ & $10.7 \%$ & $100.0 \%$ \\
\hline & & $\begin{array}{l}\% \text { within Do you } \\
\text { respect netiquettes in } \\
\text { your online } \\
\text { communication }\end{array}$ & $54.5 \%$ & $50.0 \%$ & $50.0 \%$ & $\mathbf{7 7 . 8 \%}$ & $\mathbf{5 0 . 0 \%}$ & $56.0 \%$ \\
\hline & & $\%$ of Total & $12.0 \%$ & $18.0 \%$ & $6.0 \%$ & $14.0 \%$ & $6.0 \%$ & $56.0 \%$ \\
\hline \multirow[t]{4}{*}{ Total } & & Count & 11 & 18 & 6 & 9 & 6 & 50 \\
\hline & & $\%$ within Age & $22.0 \%$ & $36.0 \%$ & $12.0 \%$ & $18.0 \%$ & $12.0 \%$ & $100.0 \%$ \\
\hline & & $\begin{array}{l}\% \text { within Do you } \\
\text { respect netiquettes in } \\
\text { your online } \\
\text { communication }\end{array}$ & $100.0 \%$ & $100.0 \%$ & $100.0 \%$ & $100.0 \%$ & $100.0 \%$ & $100.0 \%$ \\
\hline & & $\%$ of Total & $22.0 \%$ & $36.0 \%$ & $12.0 \%$ & $18.0 \%$ & $12.0 \%$ & $100.0 \%$ \\
\hline
\end{tabular}

The cross-tabulation is done to assess whether the age factor affects respondents' respect of netiquettes in online communication. As it has been stated earlier, the age division is composed of "less than 18" and "more than 18". According to the table above, findings show that 5 respondents who represent $10 \%$ of the whole sample $(n=50)$ who "always" respect netiquettes in online communication who are 'less than 18'. For the same age categorization, 9 respondents, representing $18 \%$, opt for "usually" option in the five scales, while "sometimes" is chosen by 3 respondents, rated as 6\% from the whole sample. For "rarely", there is 2 respondents $(4 \%)$, and for those who "never" respect online netiquettes are confined to 3 respondents, referred to as $6 \%$. Respondents who are "more than 18 " are found to "always" respect online netiquettes and whose scores are represented in 6 elements with $12 \%$ from the whole sample $(n=50)$. "Usually" is 9 respondents with $(18 \%)$, while "sometimes" is selected by 3 respondents with (6\%). 7 respondents from the whole sample (n=50) who "rarely" respect the netiquettes with $(14 \%)$, but for "never", 3 respondents with $(6 \%)$ are found to respect the netiquettes. Above all, the 28 students who are "more than 18 " with 
(56\%) are found to approximately respect netiquettes in online communication in comparison to the 22 "less than 18 " students with (22\%).

Table 5: Chi-Square Tests of age and respect of netiquettes in online communication

\begin{tabular}{lccc}
\hline & Value & df & Asymp. Sig. (2-sided) \\
\hline Pearson Chi-Square & $2.180^{\mathrm{a}}$ & 4 & .703 \\
\hline Likelihood Ratio & 2.311 & 4 & .679 \\
\hline $\begin{array}{l}\text { Linear-by-Linear } \\
\text { Association }\end{array}$ & .316 & 1 & .574 \\
\hline N of Valid Cases & 50 & & \\
\hline
\end{tabular}

The above table about the Chi-square test shows that the $p$-value (.70) is not significant because the sig. value is higher than (.05) that is the average value to be significant. Thus, the null hypothesis is retained, meaning that there is no relationship between the age factor and respecting netiquettes in online communication.

\section{Table 6: Netiquettes and building relationships online}

\begin{tabular}{|c|c|c|c|c|c|}
\hline & & & \multicolumn{2}{|c|}{$\begin{array}{c}\text { Do netiquettes help you build relationships } \\
\text { online? }\end{array}$} & \multirow[t]{2}{*}{ Total } \\
\hline & & & Yes & No & \\
\hline \multirow[t]{8}{*}{ Age } & \multirow{4}{*}{$\begin{array}{l}\text { Less than } \\
18\end{array}$} & Count & 11 & 11 & 22 \\
\hline & & $\%$ within Age & $50.0 \%$ & $\mathbf{5 0 . 0 \%}$ & $100.0 \%$ \\
\hline & & $\begin{array}{l}\% \text { within do netiquettes help } \\
\text { you build relationships } \\
\text { online }\end{array}$ & $39.3 \%$ & $50.0 \%$ & $44.0 \%$ \\
\hline & & $\%$ of Total & $22.0 \%$ & $22.0 \%$ & $44.0 \%$ \\
\hline & \multirow{4}{*}{$\begin{array}{l}\text { More } \\
\text { than } 18\end{array}$} & Count & 17 & 11 & 28 \\
\hline & & $\%$ within Age & $60.7 \%$ & $39.3 \%$ & $100.0 \%$ \\
\hline & & $\begin{array}{l}\% \text { within do netiquettes help } \\
\text { you build relationships } \\
\text { online }\end{array}$ & $60.7 \%$ & $\mathbf{5 0 . 0 \%}$ & $56.0 \%$ \\
\hline & & $\%$ of Total & $34.0 \%$ & $22.0 \%$ & $56.0 \%$ \\
\hline \multirow[t]{4}{*}{ Total } & & Count & 28 & 22 & 50 \\
\hline & & $\%$ within Age & $56.0 \%$ & $44.0 \%$ & $100.0 \%$ \\
\hline & & $\begin{array}{l}\% \text { within do netiquettes help } \\
\text { you build relationships } \\
\text { online }\end{array}$ & $100.0 \%$ & $100.0 \%$ & $100.0 \%$ \\
\hline & & $\%$ of Total & $56.0 \%$ & $44.0 \%$ & $100.0 \%$ \\
\hline
\end{tabular}

The cross-tabulation is done to assess whether the age factor affects the item which states the importance of netiquettes in helping respondents build online relationships. As it has been stated earlier, the age division is composed of "less than 18 " and "more than 18 ". According to the table above, findings show that 11 respondents from those who are "less than 18 " represent $22 \%$ of the whole sample $(\mathrm{n}=50)$ and who agreed upon building online relationships when netiquettes are respected. For the same age categorization, 11 respondents, representing $22 \%$, who opt for "NO" option indicate that they see the opposite. Respondents who are "more than 18 " are found to confirm that netiquettes help students to build online relationships since 17 respondents, representing $34 \%$ opt of 'Yes' option, while 11 participants, representing $22 \%$ of those who choose 'No' option. Thus, the adopted crosstab indicates that respondents who are more and "less than 18 " are found to see 
that netiquettes help to build online relationships and that there is a slight difference between the two categories in their perceptions towards the asked question.

Table 7: Gender and respect of netiquettes in online communication

\begin{tabular}{|c|c|c|c|c|c|c|c|c|}
\hline \multirow{8}{*}{ Gender } & & & \multicolumn{5}{|c|}{ Do you respect netiquettes in your online communication? } & \multirow[t]{2}{*}{ Total } \\
\hline & & & Always & Usually & Sometimes & Rarely & Never & \\
\hline & \multirow[t]{3}{*}{ Male } & Count & 5 & 6 & 4 & 7 & 3 & 25 \\
\hline & & $\begin{array}{l}\% \text { within Do you } \\
\text { respect netiquettes in } \\
\text { your online } \\
\text { communication }\end{array}$ & $45.5 \%$ & $33.3 \%$ & $66.7 \%$ & $\mathbf{7 7 . 8 \%}$ & $\mathbf{5 0 . 0 \%}$ & $\mathbf{5 0 . 0 \%}$ \\
\hline & & $\%$ of Total & $10.0 \%$ & $12.0 \%$ & $8.0 \%$ & $14.0 \%$ & $6.0 \%$ & $\mathbf{5 0 . 0 \%}$ \\
\hline & \multirow[t]{3}{*}{ Female } & Count & 6 & 12 & 2 & 2 & 3 & 25 \\
\hline & & $\%$ within Gender & $24.0 \%$ & $48.0 \%$ & $8.0 \%$ & $8.0 \%$ & $12.0 \%$ & $100.0 \%$ \\
\hline & & $\begin{array}{l}\% \text { within Do you } \\
\text { respect netiquettes in } \\
\text { your online } \\
\text { communication }\end{array}$ & $54.5 \%$ & $66.7 \%$ & $33.3 \%$ & $22.2 \%$ & $50.0 \%$ & $\mathbf{5 0 . 0 \%}$ \\
\hline \multirow{3}{*}{ Total } & & $\%$ within Gender & $22.0 \%$ & $36.0 \%$ & $12.0 \%$ & $18.0 \%$ & $12.0 \%$ & $100.0 \%$ \\
\hline & & $\begin{array}{l}\% \text { within Do you } \\
\text { respect netiquettes in } \\
\text { your online } \\
\text { communication }\end{array}$ & $100.0 \%$ & $100.0 \%$ & $100.0 \%$ & $\begin{array}{c}100.0 \\
\%\end{array}$ & $100.0 \%$ & $100.0 \%$ \\
\hline & & $\%$ of Total & $22.0 \%$ & $36.0 \%$ & $12.0 \%$ & $18.0 \%$ & $12.0 \%$ & $100.0 \%$ \\
\hline
\end{tabular}

The cross-tabulation is done to assess whether the gender factor affects respondents' respect of netiquettes in online communication. As it has been stated earlier, the gender division is composed of male and female respondents. According to the table above, findings show that $\mathbf{5}$ male respondents who represent $10 \%$ of the whole sample $(n=50)$ who "always" respect netiquettes in online communication. For the same gender categorization, 6 respondents, representing $12 \%$, opt for "usually" option in the five scales, while "sometimes" is chosen by 4 respondents, rated as $8 \%$ from the whole sample. For "rarely", there is 7 respondents $(14 \%)$, and for those who "never" respect online netiquettes are confined to 3 respondents, referred to as $12 \%$. Respondents who are "always" respecting online netiquettes and whose scores are represented in 6 elements with $12 \%$ from the whole sample $(\mathrm{n}=50)$. "Usually" is 12 respondents with $(24 \%)$, while "sometimes" is selected by 2 respondents with (4\%). 2 respondents from the whole sample $(n=50)$ who "rarely" respect the netiquettes with (4\%), but for "never", 3 respondents with (6\%) are found to respect the netiquettes. Above all, it is found that female respondents tend to respect more the netiquettes when online in comparison with male choices. 
Table 8: Chi-Square Tests of gender and respecting netiquettes in online communication

\begin{tabular}{lccc}
\hline & Value & df & Asymp. Sig. (2-sided) \\
\hline Pearson Chi-Square & $5.535^{\mathrm{a}}$ & 4 & .237 \\
\hline Likelihood Ratio & 5.751 & 4 & .219 \\
\hline Linear-by-Linear Association & 1.887 & 1 & .170 \\
\hline N of Valid Cases & 50 & & \\
\hline
\end{tabular}

The above table about the Chi-square test shows that the $p$-value $(\mathbf{2 3})$ is not significant because the sig. value is higher than (.05) that is the average value to be significant. Thus, the null hypothesis is retained, meaning that there is no relationship between the gender factor and respecting netiquettes in online communication.

Table 9: Chi-Square Tests of age and building online relationships with respect to netiquettes

\begin{tabular}{lccc}
\hline & Value & df & Asymp. Sig. (2-sided) \\
\hline Pearson Chi-Square & $.574^{\mathrm{a}}$ & 1 & .449 \\
\hline Continuity Correction $^{\mathrm{b}}$ & .222 & 1 & .638 \\
\hline Likelihood Ratio & .574 & 1 & .449 \\
\hline Linear-by-Linear Association $^{\text {N of Valid Cases }}$ & .562 & 1 & .453 \\
\hline
\end{tabular}

The above table about the Chi-square test shows that the $p$-value (.44) is not significant because the sig. value is higher than (.05) that is the average value to be significant. Thus, the null hypothesis is retained, meaning that there is no relationship between the age factor and building online relationships when netiquettes are respected.

\section{Hypothesis testing}

Table 10: Chi-Square Tests of the association between the respect of netiquettes and building relationships online

\begin{tabular}{lccc} 
& Value & df & Asymp. Sig. (2-sided) \\
\hline Pearson Chi-Square & $21.488^{\mathrm{a}}$ & 4 & .000 \\
\hline Likelihood Ratio & 24.769 & 4 & .000 \\
\hline Linear-by-Linear Association & 12.127 & 1 & .000 \\
\hline N of Valid Cases & 50 & &
\end{tabular}

The table above, conducting the Chi-square test, shows that there is a significant relationship between the respect of netiquettes and online relationship building because the p-value (.000) is less than (.05) which the significance average. This result confirms the null hypothesis set for this research study: there is a predictive link between the respect of netiquettes and relationship building online.

Table 11: Distribution of pre-knowledge about netiquettes

\begin{tabular}{cccccc}
\hline \multirow{2}{*}{ Valid } & & Frequency & Percent & Valid Percent & Cumulative Percent \\
\cline { 2 - 6 } & Yes & 25 & 50.0 & 50.0 & 50.0 \\
\cline { 2 - 6 } & No & 25 & 50.0 & 50.0 & 100.0 \\
\cline { 2 - 6 } & Total & 50 & 100.0 & 100.0 & \\
\hline
\end{tabular}


The findings of item 3 reveal that respondents who have already heard of netiquettes are similar to those who have never heard of them. A total of 25 respondents, representing $50 \%$, out of $n=50$ have already heard about netiquettes, while a total of 25 , representing $50 \%$, out of $n=50$ have never heard of netiquettes. This invokes that those who have pre-knowledge about netiquettes may have transferred them from F-t-F social etiquettes to online communication. So, half of the sample is aware of the respect of netiquettes to an extent.

\section{Table 12: Perception of netiquettes}

\begin{tabular}{llccc}
\hline \multirow{3}{*}{ Valid } & Frequency & Percent & Valid Percent \\
\cline { 2 - 5 } & Very important & 14 & 28.0 & 28.0 \\
\cline { 2 - 5 } & Important & 21 & 42.0 & 42.0 \\
\cline { 2 - 5 } & Undecided & 9 & 18.0 & 18.0 \\
\cline { 2 - 5 } & Less important & 6 & 12.0 & 12.0 \\
\cline { 2 - 5 } & Total & 50 & 100.0 & 100.0 \\
\hline
\end{tabular}

The table above displays the frequencies of respondents' perceptions towards netiquettes. A total of $14(28 \%)$ respondents out of $n=50$ see that netiquettes are 'very important', and a total of 21 $(42 \%)$ respondents out of $n=50$ perceive netiquettes as 'important', while a total of $9(18 \%)$ respondents out of $\mathrm{n}=50$ opt for the 'undecided' option, and only 6 respondents, representing $12 \%$ out of $n=50$ have ticked the 'less important' choice. The findings of this item as shown above indicate that $70 \%$ (35) respondents out $n=50$, representing the majority of the whole sample see netiquettes in online communication either as very important or important. This shows that human communication requires some transformations of social ethics from the real world to the virtual, namely netiquettes.

\section{RESULTS DISCUSSION}

The study tries to investigate the respect of netiquettes and its impact on building relationships in an online learning community. The focus was on University students of the faculty of arts and humanities in Meknes who belong to a 'Facebook' group whose interest is in sharing knowledge, up-dated information, and other issues related to learning English as a foreign language. The main objectives of this study were to explore the impact of the perceptions of respecting netiquettes on building online relationships.

After having conducted cross-tabulation for the age factor and its association with respecting etiquettes in both F-t-F communication and netiquettes in online communication, there is no significant association, meaning that the age of students in higher education does not have any impact on the respect of etiquettes and netiquettes. Both students who are "less than 18 " and "more than 18", which indicates the age of adultness, is not a determinant factor in transforming F-t-F social etiquettes to online netiquettes. This means that both age segments are aware of the importance of respecting the rules of interaction in the community. 
Table 13: Frequency distribution of netiquettes practicing

\begin{tabular}{|c|c|c|c|c|}
\hline \multirow{2}{*}{ Items } & \multicolumn{2}{|c|}{$\begin{array}{l}\text { Respecting netiquettes } \\
\text { Respondents } \\
\text { Percentage }\end{array}$} & \multicolumn{2}{|c|}{$\begin{array}{c}\text { Not respecting netiquettes } \\
\text { Respondents } \\
\text { Percentage }\end{array}$} \\
\hline & 33 & $66 \%$ & 17 & $34 \%$ \\
\hline $\begin{array}{l}\text { Do you include salutations with your real name } \\
\text { while posting? }\end{array}$ & 33 & $66 \%$ & 17 & $34 \%$ \\
\hline $\begin{array}{l}\text { Do you refer to original writers when you quote } \\
\text { from them? }\end{array}$ & 27 & $54 \%$ & 23 & $46 \%$ \\
\hline Are your postings short? & 29 & $\mathbf{5 8 \%}$ & 21 & $42 \%$ \\
\hline $\begin{array}{l}\text { Do you include acronyms or abbreviations } \\
\text { during your discussions }\end{array}$ & 18 & $36 \%$ & 32 & $64 \%$ \\
\hline Do you use emoticons to express your feelings? & 13 & $26 \%$ & 37 & $74 \%$ \\
\hline $\begin{array}{l}\text { Do you respect grammar and punctuation rules } \\
\text { in your posting? }\end{array}$ & 35 & $70 \%$ & 15 & $30 \%$ \\
\hline $\begin{array}{l}\text { Do you revise your postings and correct } \\
\text { mistakes, if any, before you share? }\end{array}$ & 28 & $56 \%$ & 22 & $44 \%$ \\
\hline $\begin{array}{l}\text { Do you write phrases or sentences with capital } \\
\text { letters in your posting? }\end{array}$ & 17 & $34 \%$ & 33 & $66 \%$ \\
\hline $\begin{array}{l}\text { Do you consider members of the group as } \\
\text { human beings while communicating? }\end{array}$ & 38 & $76 \%$ & 12 & $24 \%$ \\
\hline $\begin{array}{l}\text { Do you refer to online friends by their real } \\
\text { names? }\end{array}$ & 36 & $72 \%$ & 14 & $28 \%$ \\
\hline Do you share spam with your friends? & 30 & $60 \%$ & 20 & $40 \%$ \\
\hline $\begin{array}{l}\text { Does real identification help you build } \\
\text { relationships online? }\end{array}$ & 31 & $62 \%$ & 19 & $38 \%$ \\
\hline
\end{tabular}

The table above illustrates the results of the data collected on students' practicing netiquettes in the online learning community. Students are found to be divided into classes: the first class includes those who respect netiquettes, while the second class includes those who do not respect netiquettes. Both classes were examined on the basis of respecting the following netiquettes: authentic profile, greetings, originality, short postings, acronyms, and abbreviations, emoticons, grammar and punctuation rules, revising and correcting mistakes, capitalization, human consideration, real name reference, spam sharing, and real identification in building relationships. There are 13 items upon which the frequencies are based. It has been found that students respect netiquettes in 10 items and they do not respect them in 3 items. For example, 38 respondents out of $\mathrm{n}=50$, representing $76 \%$ consider their peers as human. Moreover, 36 respondents out of $\mathrm{n}=50$, representing $72 \%$ who respect the netiquettes in terms of communicating with their real names. However, the results show that students in higher education do not respect netiquettes only in 3 items among the 13 ones. Firstly, 32 respondents out of $n=50$ with $64 \%$ use acronyms and abbreviations in their postings or comments in the group. Secondly, netiquettes are not respected in terms of including emoticons while communicating. In this issue, statistics show that 37 respondents out of $n=50$, rated as $74 \%$ who use emoticons instead of academic writing. Thirdly, 33 respondents out of $n=50$, referred to by $66 \%$ write in capital letters, meaning that academic ways of writing are still violated because they break the rule of the writing style. 


\section{The Role of Netiquettes in Establishing Relationships in Virtual Learning Communities}

From the gender perspective, the cross-tabulation findings of gender and respecting online netiquettes demonstrate that females tend to outdo males in frequencies of the scale, thought the Chi-square test shows that there is no significant relationship between the two variables. These findings reveal that females are respectful to social and cultural rules of communication. Finally, the gender construct, according to this study, is not static but flexible element in the measurement of individual differences.

The results of questionnaire demonstrate that the null hypothesis "when students of higher education respect netiquettes or network etiquettes, social relationships in learning are constructed" is confirmed when having conducted the Chi-square test, claiming that there is a significant relationship between the respect of netiquettes in higher education and building social relationships in learning. Testing the hypothesis has .000 as a p-value. In other words, when students respect netiquettes online, they are able to construct social relationships.

\section{CONCLUSION}

Based on the findings and discussion, it can be resumed that respecting netiquettes in an online learning community plays a primordial role in establishing relationships online. Since netiquettes (network etiquettes) are originated from social (face-to-face) etiquettes, students in higher education are found to respect the majority of the online rules that determine the establishment of online relationships. Investigating this kind of relationship from the gender and age perspectives indicates that there is no significant association with online relationship construction. However, some students are affected by the medium in violating some rules such as acronyms and abbreviations, emoticons, and capitalization style.

\section{RECOMMENDATIONS}

Depending on the results achieved in this study, some recommendations can be suggested in relation to netiquettes and their implementation in the online learning environment. First and foremost, learners of English as a foreign language should be taught how to be critical thinkers in the sense that taking into consideration their readers is a matter of fact that makes them choose the style of their language. By writing in capitalized letters while communicating online is a kind of insult for one's readers. Thus, being aware of others as human beings who can detect feelings through graphics makes community members avoid spoiling the learning atmosphere.

The second recommendation might have to with andragogy in higher education. Implementing online learning communities in higher education as a compensation for face-toface classrooms necessitates the integration of the netiquettes as a part of the content of the syllabi. In the same respect, university professors are expected to include the netiquettes in the selection of materials, especially in reading comprehension, oral communication, and study skills courses. This may raise the students as well as the online users' awareness of respecting the minimum rate of the golden rules of netiquettes.

Last but not least, a third recommendation might have focus on academic writing. In the findings, students are found to use acronyms and abbreviations, emoticons, and capitalization. In such a case, university professors are expected to invest in students' academic writing skills to develop their performance. Formal instruction is needed to increase students' awareness of giving value to their productive skill in writing. Moreover, violating the rules of academic 
writing may create misunderstandings among members of the group that's why the instructor's role is to select the best approach and method that suit his/her learners' needs.

\section{REFERENCES}

Creswell, J. W. (2007) Qualitative Inquiry \& Research Design: Choosing Among Five Approaches.(2nd ed.) Thousand Oaks, CA: SAGE Publications

Kayany, J. M. (2004). Internet Etiquette (Netiquette). The Internet Encyclopedia.

Miller, S. (2001) E-Mail Etiquette: Do's, don'ts, and disaster tales people magazine's internet manners expert. New York: Warner Books.

Shea, V. (1994). Netiquette. New York: Albion Books.

Stake, R. (1995). The art of case study research. Thousand Oaks, CA: Sage.

Wood, A. F., \& Smith, M. J. (2004). Online communication: Linking technology, identity, \& culture. Routledge. 